\title{
Phytoremediation Potential of Three Species of Macrophytes for Nitrate in Contaminated Water
}

\author{
Kun Li, Lili Liu, Huanxiang Yang, Caihong Zhang, Huicheng Xie, Chuanrong $\mathrm{i}^{*}$ \\ Taishan Forest Ecosystem Research Station/Key Laboratory of Agricultural Ecology and Environment, \\ Shandong Agricultural University, Taian, China \\ Email: "chrli@sdau.edu.cn
}

Received 24 May 2016; accepted 17 June 2016; published 20 June 2016

Copyright (C) 2016 by authors and Scientific Research Publishing Inc.

This work is licensed under the Creative Commons Attribution International License (CC BY). http://creativecommons.org/licenses/by/4.0/

(c) $\underset{\mathrm{EY}}{\mathrm{E}}$ Open Access

\section{Abstract}

Three species of aquatic plants (Scirpus validus, Phragmites australis and Acorus calamus) were used as experimental materials to study their capacity to purify contaminated water and their effects on water $\mathrm{pH}$ and dissolved oxygen (DO). The water was contaminated with different concentrations of nitrate $(5 \mathrm{mg} / \mathrm{L}, 15 \mathrm{mg} / \mathrm{L}$ and $25 \mathrm{mg} / \mathrm{L})$. The results indicated that the concentration of nitrate, species of aquatic plant and their interaction significantly impacted denitrification $(P=$ 0.00). Under the same concentrations, the three species of aquatic plants provided varying degrees of purification. Acorus calamus provided effective purification under all three concentrations of nitrate wastewater, with removal percentages of $87.73 \%, 83.80 \%$ and $86.72 \%$ for nitrate concentrations of $5 \mathrm{mg} / \mathrm{L}, 15 \mathrm{mg} / \mathrm{L}$ and $25 \mathrm{mg} / \mathrm{L}$, respectively. In terms of the purification ability by unit fresh weight, Acorus calamus exhibited the worst purification capacity, whereas the capacities of Scirpus validus and Phragmites australis were higher. The purification capacity of Scirpus validus for the three concentrations was as follows: $0.08 \mathrm{mg} /(\mathrm{L} \cdot \mathrm{g} \mathrm{FW}), 0.29 \mathrm{mg} /(\mathrm{L} \cdot \mathrm{g} \mathrm{FW})$, and 0.51 $\mathrm{mg} /(\mathrm{L} \cdot \mathrm{g}$ FW). The capacity of Phragmites australis was $0.07 \mathrm{mg} /(\mathrm{L} \cdot \mathrm{g} \mathrm{FW}), 0.25 \mathrm{mg} /(\mathrm{L} \cdot \mathrm{g} \mathrm{FW})$, and $0.53 \mathrm{mg} /(\mathrm{L} \cdot \mathrm{g} \mathrm{FW})$. The capacity of Acorus calamus was $0.04 \mathrm{mg} /(\mathrm{L} \cdot \mathrm{g} \mathrm{FW}), 0.12 \mathrm{mg} /(\mathrm{L} \cdot \mathrm{g} \mathrm{FW})$, and $0.21 \mathrm{mg} /(\mathrm{L} \cdot \mathrm{g} \mathrm{FW})$. Under increased concentrations of nitrate, the three species of aquatic plants exhibited various degrees of increased purification capacity. Under the different concentrations of nitrate, the three species exhibited the same trends with respect to water $\mathrm{pH}$ and DO, increasing first and then falling. The $\mathrm{pH}$ remained at approximately 7.5 , and the DO fell to $4.0 \mathrm{mg} / \mathrm{L}$. A comprehensive analysis reveals that Acorus calamus provides excellent nitrate purification, although by unit fresh weight, both Scirpus validus and Phragmites australis provide superior purification capacity.

\footnotetext{
${ }^{*}$ Corresponding author.
}

How to cite this paper: Li, K., Liu, L.L., Yang, H.X., Zhang, C.H., Xie, H.C. and Li, C.R. (2016) Phytoremediation Potential of Three Species of Macrophytes for Nitrate in Contaminated Water. American Journal of Plant Sciences, 7, 1259-1267. 
Keywords

Nitrate, pH, DO, Purification Ability, Macrophytes

\section{Introduction}

Water eutrophication results primarily from the massive introduction of nutritive salts, particularly ammonium and nitrate [1]. In recent years, high levels of nitrogen fertilizer and an increasing intensity of human activities (animal husbandry, atmospheric deposition and industrial waste water discharge) have caused considerable nitrate enrichment of surface waters [2]. This enrichment has led to several environment problems, such as an increase in the concentration of nitrate-nitrogen in underground and surface water [3] and possessed a serious threat to human health and water security. The concentrations of different forms of inorganic nitrogen in wastewater can be particularly high. With respect to the sewage concentrations of nitrate, nitrogen levels can reach 99\% [4]. China's environmental bulletin (2014) reported that the average groundwater nitrate content was $10.9 \mathrm{mg} / \mathrm{L}$, and even drinking water in some places had levels greater than $50 \mathrm{mg} / \mathrm{L}$ [5]. Furthermore, the average vegetable growing areas had the highest groundwater nitrate content of approximately $15.6 \mathrm{mg} / \mathrm{L}$. Currently, only $10.8 \%$ of China's water is considered high quality, with an increasing proportion of water eutrophication and other water pollution; consequently, the water shortage situation has become increasingly serious. A long-term study of eutrophication focused mainly on responses to ammonium and its effects, and less on nitrate removal efficiency [6]. In the nitrogen cycle, nitrate serves as a substrate for microbial activity, and it is also the most active nitrogen form [7]. Although nitrate is non-toxic, its microbial metabolites can cause cancer, and nitrate concentrations in drinking water exceeding $45 \mathrm{mg} / \mathrm{L}$ can be harmful to babies' health, causing "blue baby" syndrome [2] [8]. Thus, meaningful nitrate removal from water must be a priority.

Many methods exist to address water eutrophication, including physical methods, chemical methods, and biological methods. However, physical methods and chemical methods present certain disadvantages, such as high cost, sophisticated operations, and causing secondary pollution. Biological methods, mainly involving the planting of aquatic plants to purify wastewater [1], are relatively low cost and provide considerable benefits. Especially in the south of China, these methods are widely applied to address eutrophication. We have studied many purification efficiency methods in higher aquatic plants, such as Elodea nuttallii, Eichhornia crassipes, Potamogeton crispus, Acorus tatarinowii and other species [7] [9]-[11]. Temperatures in northern China are relatively lower than those in the south, and the growing season is shorter in the north [12]. Few aquatic plant species are suitable for sewage treatment. In the process of purifying water, several physical and chemical changes occur, mainly to the water $\mathrm{pH}$ and dissolved oxygen (DO) [13]. These changes influence the growth of plants and the activity of aquatic microorganisms [14] [15] and consequently affect nitrate removal efficiency; but people pay less attention to the purification of nitrate nitrogen and the change of $\mathrm{pH}$ and $\mathrm{DO}$. Therefore, changes in the water $\mathrm{pH}$ and $\mathrm{DO}$ can be investigated to help understand eutrophication remediation efforts.

Based on the severity of nitrate pollution and water eutrophication and above problems of nitrate and $\mathrm{pH}$ and DO, this study used nitrate as a single contaminant and selected three aquatic plants that were commonly considered effective purifiers of nitrogen and phosphorus for the experiment. The purification capacity of different concentrations of nitrate was analyzed. The results can serve as a basis for the prevention and control of water eutrophication. By analyzing the purification capabilities of different plants on specific nitrate concentrations, we can provide a theoretical basis for the prevention and control of water eutrophication.

\section{Materials and Methods}

\subsection{Materials}

Three common plant species were collected from the Shuxi River in Taian for use in the experiment: Scirpus validus, Phragmites australis, and Acorus calamus. The test materials were collected in mid-April. Robust and healthy plants were collected, 50 individuals of each species; the sediment and plankton were removed from the surface of the roots with tap water in the laboratory, and the withered and yellow leaves were removed. Then, the plants were transferred to $20 \mathrm{~L}$ buckets with $15 \mathrm{~L}$ tap water; after exposure to the sun for five days, the plants underwent two weeks of cultivation and domestication in the artificial greenhouse of Shandong Agricultural 
University to become adapted to the greenhouse environment. After domestication, the plants were ready for the simulation test.

\subsection{Experimental Measurements and Calculations}

The culture solution was based on the Hoagland culture solution, with $\mathrm{KNO}_{3}$ added; three nitrate concentrations were established- $5 \mathrm{mg} / \mathrm{L}, 15 \mathrm{mg} / \mathrm{L}$ and $25 \mathrm{mg} / \mathrm{L}$ - and the $20 \mathrm{~L}$ blue plastic bucket was used as the culture container with the $15 \mathrm{~L}$ nutrient solution. Three individuals of the same species were fixed to the top with a foam board and wrapped in a black plastic bag to keep the bucket in a dark state. Each treatment included three repetitions; one plant was used as the control group, and Scirpus validus, Phragmites australis and Acorus calamus treatments were named S5, S15, S25; P5, P15, P25; and A5, A15, P25 in 5 mg/L, 15 mg/L and 25 mg/L nitrate concentrations, respectively. Nitrate was the sole nitrogen source, and denitrification or mineralization in water was the process of decomposition; the determination of the total nitrogen content of the water was used to indicate the removal of nitrate. At the start, a portable water quality analyzer (HI9828 HANNA, US) was used to determine the $\mathrm{pH}$ and $\mathrm{DO}$; at the same time, water samples were taken and the total nitrogen content was determined with a TOC (N/C multi 3100, Germany) and the nitrogen content in plants was evaluated with an elemental analyzer (ECS4010 Costech, Italy). In all of the treatments, the experiment ended when the total nitrogen concentration in the water was lower than $2.0 \mathrm{mg} / \mathrm{L}$, and the experiment lasted for 35 days. The nitrate removal percentage and plant purification capacity calculation formula is as follows:

$\%$ Nitrate Removal $(W)$ :

$$
W=\frac{C_{0}-C_{i}}{C_{0}} \times 100 \%
$$

Purification ability of plants $(M)$ :

$$
M=\frac{C_{0}-C_{i}}{\mathrm{FW}}
$$

where $C_{0}$ is the initial concentration of nitrate $(\mathrm{mg} / \mathrm{L}), C_{i}$ is the concentration of nitrate after 1 week under plant purification, and FW refers to the fresh weight of plants.

\subsection{Statistical Analysis}

The data were entered into Microsoft Excel 2013 and an Origin 9.0 spreadsheet. All of the representative values were displayed as the mean value and standard deviation (S.D.). Significant differences among treatments were determined with an analysis of variance (ANOVA) in SAS 9.0. A P-value of less than 0.05 was considered statistically significant.

\section{Results}

\subsection{Plant Growth}

The three species of emergent plants with the same growth states were transplanted into different concentrations of nitrate, cultured for five weeks, and then measured for the fresh weight. The results indicate that all three species exhibited normal growth. All three species produced new roots, gemmae and adventitious roots during the test. At the end of the experiment, parts of the Phragmites australis leaves had withered and parts of the buds of Scirpus validus had also withered. However, Acorus calamus' growth status was normal. Figure 1 shows fresh weight of the three species of macrophytes at the initial of test and the end of test. At the beginning of the experiment, the fresh weights of Scirpus validus, Phragmites australis and Acorus calamus were $38 \mathrm{~g}, 37 \mathrm{~g}$ and 101 $\mathrm{g}$; after the test, the average weight gain was $21 \%, 8 \%$ and $26 \%$, respectively. The weight gain of the emergent plants increased along with the increase in nitrate.

\subsection{Biometric Characteristics}

Table 1 shows that the removal efficiency of aquatic plants on nitrate is influenced by the concentration and plant species and the interaction between them $(P=0.000)$. Under different concentrations of nitrate, the removal efficiency of plants was significantly different (Table 2, $P<0.01$ ); with increased concentrations of nitrate, the removal percentage of plants increased and the nitrate removal percentage was $81.62 \%$ at a concentration of 


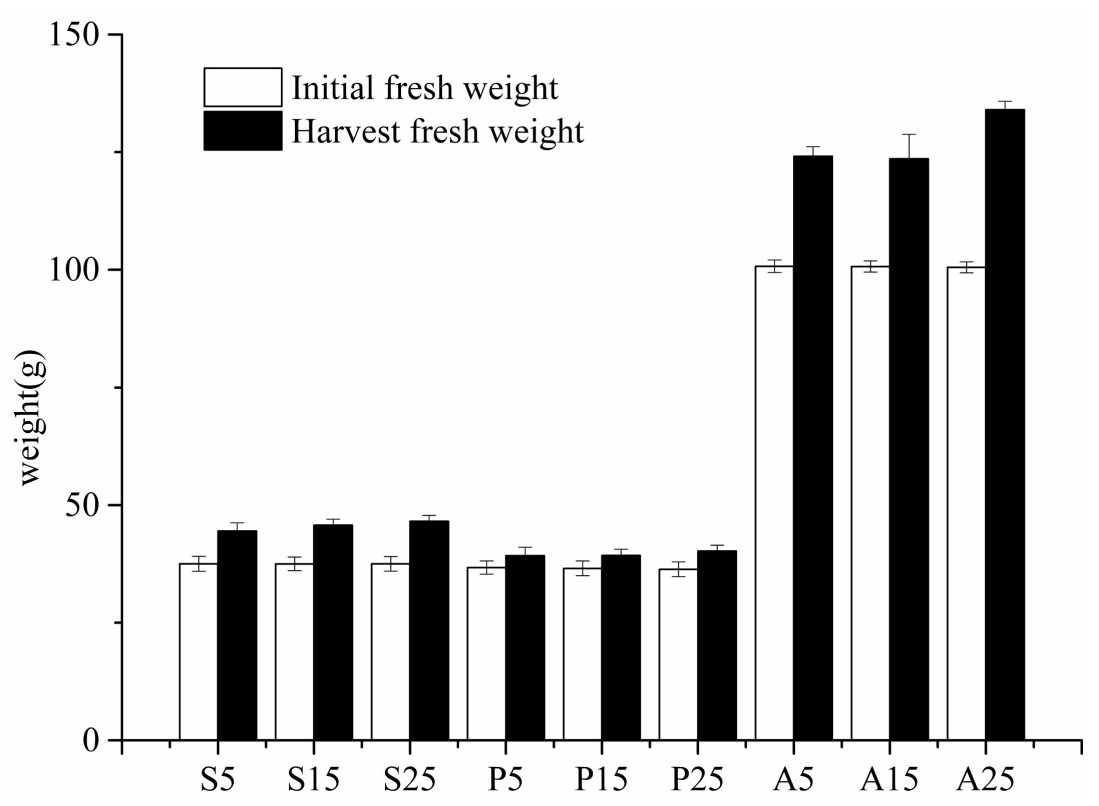

Figure 1. Change in hydrophyte biomass.

Table 1. Effect of nitrate concentration and plant type on nitrate removal.

\begin{tabular}{cccc}
\hline & df. & F & Sig. \\
\hline Nitrate concentration & 2 & 426.494 & 0.000 \\
Plant type & 2 & 874.821 & 0.000 \\
Nitrate concentration $\times$ plant type & 4 & 137.807 & 0.000 \\
\hline
\end{tabular}

Table 2. The removal percentages of plants under different concentrations and comparison of the removal percentages of different plant types.

\begin{tabular}{cccc}
\hline Concentration $(\mathrm{mg} / \mathrm{L})$ & Final nitrate removal & Plants & Final nitrate removal \\
\hline 5 & $0.6473 \mathrm{c}$ & Scirpus validus & $0.6234 \mathrm{c}$ \\
15 & $0.7118 \mathrm{~b}$ & Phragmites australis & $0.6874 \mathrm{~b}$ \\
25 & $0.8162 \mathrm{a}$ & Acorus calamus & $0.8616 \mathrm{a}$ \\
\hline
\end{tabular}

Note: different letters indicate significant difference $(P<0.05)$ among the treatments.

$25 \mathrm{mg} / \mathrm{L}$. There was a highly significant difference among the three types of aquatic plants with respect to the removal percentage of nitrate (Table 2, $P<0.01$ ). The nitrate removal percentage of Acorus calamus was highest, reaching $86.16 \%$, and the nitrate removal percentage of Phragmites australis was significantly lower than the other two species, at only $62.34 \%$.

\subsection{Nitrate Removal Potential of the Tested Species}

Statistically significant increases in N removal were observed under increasing N concentrations in Scirpus validus in treated water. Among the concentrations, the highest mean nitrate removal occurred at $25 \mathrm{mg} / \mathrm{L}$, with a total removal of $5.32 \mathrm{mg} / \mathrm{L}$. At concentrations of $15 \mathrm{mg} / \mathrm{L}$ and $5 \mathrm{mg} / \mathrm{L}$, the amounts removed were $4.44 \mathrm{mg} / \mathrm{L}$ and $2.14 \mathrm{mg} / \mathrm{L}$, respectively. The highest $(5.86 \mathrm{mg} / \mathrm{L})$ mean $\mathrm{N}$ removal was recorded in the first weekly interval. However, removal during the 2nd, 3rd, 4th, and 5th weeks exhibited significant differences, other than the latter three weeks (Table 3). The weekly reduction of nitrate $\mathrm{N}$ by Scirpus validus under different levels of nitrate in water during the fourth week also exhibited a declining trend with increasing concentrations of nitrate in water. The highest percentage (79\%) reduction was recorded at a concentration of $25 \mathrm{mg} / \mathrm{L}$, with a removal amount of 
Table 3. Nitrate removal of Scirpus validus and total N in tissues.

\begin{tabular}{cccccc}
\hline N level & Week & $\begin{array}{c}\text { N mean } \\
\text { removal }(\mathrm{mg} / \mathrm{L})\end{array}$ & $\begin{array}{c}\text { N content end } \\
\text { of 5th week }(\mathrm{mg} / \mathrm{L})\end{array}$ & $\begin{array}{c}\text { \% removal at the } \\
\text { end of the 5th week }\end{array}$ & $\begin{array}{c}\text { Total nitrogen } \\
(\mathrm{mg} / \mathrm{g}) \text { in tissues }\end{array}$ \\
\hline $5(\mathrm{mg} / \mathrm{L})$ & 1 & $5.86 \mathrm{c}$ & $2.14 \mathrm{a}$ & 57 & 70 \\
$15(\mathrm{mg} / \mathrm{L})$ & 2 & $3.67 \mathrm{~b}$ & $4.44 \mathrm{~b}$ & 79 & $21.03 \mathrm{a}$ \\
$25(\mathrm{mg} / \mathrm{L})$ & 3 & $0.5 \mathrm{a}$ & $5.32 \mathrm{c}$ & & $22.27 \mathrm{a}$ \\
& 4 & $0.35 \mathrm{a}$ & & & \\
& 5 & $0.65 \mathrm{a}$ & & \\
\hline
\end{tabular}

Note: different letters indicate significant differences $(P<0.05)$ among the treatments.

$19.68 \mathrm{mg} / \mathrm{L}$. In comparison, $57 \%$ and $70 \%$ of $\mathrm{N}$ was removed from water under initial nitrate concentrations of 5 $\mathrm{mg} / \mathrm{L}$ and $15 \mathrm{mg} / \mathrm{L}$, respectively.

A comparison of the total nitrogen content of Scirpus validus obtained from different $\mathrm{N}$ concentrations in water indicate that plants growing under higher concentrations had a higher $\mathrm{N}$ content in their tissues (Table 3). The total N content of Scirpus validus was $22.27 \mathrm{mg} / \mathrm{g}, 21.77 \mathrm{mg} / \mathrm{g}$, and $21.03 \mathrm{mg} / \mathrm{g}$ in water with nitrate concentrations of $25 \mathrm{mg} / \mathrm{L}, 15 \mathrm{mg} / \mathrm{L}$ and $5 \mathrm{mg} / \mathrm{L}$, respectively, and the difference was not statistically significant.

There was a major increase in nitrate removal with increasing nitrate concentration in water. On average, 2.54 $\mathrm{mg} / \mathrm{L}, 6.12 \mathrm{mg} / \mathrm{L}$ and $5.14 \mathrm{mg} / \mathrm{L}$ were removed under nitrate concentrations of $5 \mathrm{mg} / \mathrm{L}, 15 \mathrm{mg} / \mathrm{L}$, and $25 \mathrm{mg} / \mathrm{L}$, respectively. The results exhibited a decreasing trend in $\mathrm{N}$ mean removal per week over time, apart from the fourth week. A higher $(6.39 \mathrm{mg} / \mathrm{L})$ mean nitrate removal percentage was observed in the first week, and the amount removed was $2.56 \mathrm{mg} / \mathrm{L}$ and $0.5 \mathrm{mg} / \mathrm{L}$ in the second and third week, respectively. The percentage of nitrate removal by Phragmites australis was also studied under different water $\mathrm{N}$ concentrations. An obvious increase in $\mathrm{N}$ removal was observed with increasing water $\mathrm{N}$ concentrations. At the end of third week, $2.54 \mathrm{mg} / \mathrm{L}$, $6.12 \mathrm{mg} / \mathrm{L}$ and $5.14 \mathrm{mg} / \mathrm{L} \mathrm{N}$ were removed from the water under initial $\mathrm{N}$ concentrations of $5 \mathrm{mg} / \mathrm{L}, 15 \mathrm{mg} / \mathrm{L}$ and $25 \mathrm{mg} / \mathrm{L}$, respectively (Table 4). The total $\mathrm{N}$ content of Phragmites australis was observed at $21.67 \mathrm{mg} / \mathrm{g}$, $20.40 \mathrm{mg} / \mathrm{g}$, and $20.33 \mathrm{mg} / \mathrm{g}$ in tissues grown in water with $\mathrm{N}$ concentrations of $25 \mathrm{mg} / \mathrm{L}, 15 \mathrm{mg} / \mathrm{L}$ and $5 \mathrm{mg} / \mathrm{L}$, respectively. The highest $(21.67 \mathrm{mg} / \mathrm{g})$ total $\mathrm{N}$ content was recorded in plants grown in water with a nitrate concentration of $25 \mathrm{mg} / \mathrm{L}$, but the difference was not statistically significant.

Table 5 shows the mean values of nitrate removal for the different levels of nitrate for a given week. The average mean $\mathrm{N}$ removals of $3.39 \mathrm{mg} / \mathrm{L}, 12.59 \mathrm{mg} / \mathrm{L}$ and $21.68 \mathrm{mg} / \mathrm{L}$ were recorded in water with initial concentrations of $5 \mathrm{mg} / \mathrm{L}, 15 \mathrm{mg} / \mathrm{L}$ and $25 \mathrm{mg} / \mathrm{L}$, respectively. In the case of Acorus calamus, the highest ( $8.13 \mathrm{mg} / \mathrm{L})$ amount of nitrate was removed in the initial week, followed by the fifth week $(2.15 \mathrm{mg} / \mathrm{L})$ and the second week $(1.29 \mathrm{mg} / \mathrm{L})$. The same removal pattern was exhibited by the other two species, for which the highest nitrate removal was recorded during the initial week. However, even in the final week, substantial removal was achieved by Acorus calamus; this could be attributed to the high $\mathrm{N}$ requirements for developing the root system in this species. Acorus calamus exhibited a general increasing trend of nitrate removal from water with increasing water nitrate concentrations. The total $\mathrm{N}$ content of Acorus calamus was observed at $21.67 \mathrm{mg} / \mathrm{g}, 20.40 \mathrm{mg} / \mathrm{g}$, and $20.33 \mathrm{mg} / \mathrm{g}$ in tissues grown in water with $\mathrm{N}$ concentrations of $25 \mathrm{mg} / \mathrm{L}, 15 \mathrm{mg} / \mathrm{L}$ and $5 \mathrm{mg} / \mathrm{L}$, respectively. The highest percentage (87\%) reduction occurred under a concentration of $25 \mathrm{mg} / \mathrm{L}$, whereas the lowest percentage (68\%) reduction was recorded under a concentration of $5 \mathrm{mg} / \mathrm{L}$.

\subsection{Purification Ability of Tested Plants}

The purification ability of different species under the same concentration of nitrate and the purification ability of the same species under different concentrations of nitrate are illustrated in Figure 2. Under the same concentration of nitrate, the three species exhibited significant differences in nitrate purification capacity (except P25 and S25). The purification ability of Acorus calamus was substantially lower than those of the other two species under an initial nitrate concentration of $15 \mathrm{mg} / \mathrm{L}$, which was $49.60 \%$ for Scirpus validus and $43.28 \%$ for Phragmites australis, whereas these values were $39.75 \%$ and $41.29 \%$, respectively, under a concentration of $25 \mathrm{mg} / \mathrm{L}$. The purification ability of the same species under different nitrate concentrations were significantly different $(P<$ 0.05). With an increase in the concentration of nitrate, the purification capacity increased, and the purification 


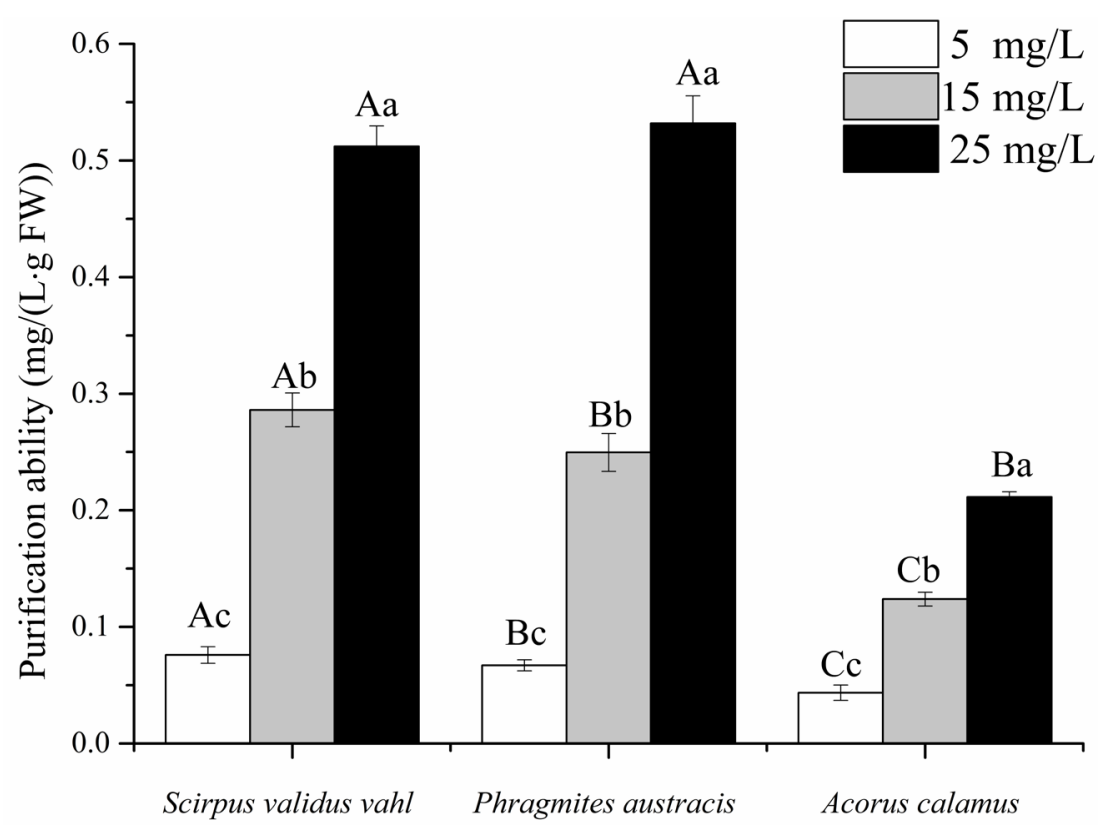

Figure 2. The nitrate purification ability of different species. Note: a, b, and c denote differences in the purification ability under different nitrate concentrations in the same species; A, B, and C show the difference in the purification ability under the same nitrate concentration in different species.

Table 4. Nitrate removal by Phragmites australis and total $\mathrm{N}$ in tissues.

\begin{tabular}{|c|c|c|c|c|c|}
\hline $\mathrm{N}$ level & Week & $\begin{array}{l}\mathrm{N} \text { mean } \\
\text { removal (mg/L) }\end{array}$ & $\begin{array}{l}\mathrm{N} \text { content at the end } \\
\text { of } 5 \text { th week }(\mathrm{mg} / \mathrm{L})\end{array}$ & $\begin{array}{l}\% \text { removal at the end } \\
\text { of } 5 \text { th week }\end{array}$ & $\begin{array}{l}\text { Total nitrogen } \\
(\mathrm{mg} / \mathrm{g}) \text { in tissues }\end{array}$ \\
\hline 5 (mg/L) & 1 & 6.39d & $2.54 \mathrm{a}$ & 49 & $20.33 a$ \\
\hline 15 (mg/L) & 2 & $2.56 \mathrm{c}$ & $6.12 \mathrm{c}$ & 59 & $20.40 a$ \\
\hline \multirow[t]{3}{*}{25 (mg/L) } & 3 & $0.5 a b$ & $5.14 \mathrm{~b}$ & 79 & $21.67 a$ \\
\hline & 4 & $0.68 b$ & & & \\
\hline & 5 & $0.27 \mathrm{a}$ & & & \\
\hline
\end{tabular}

Table 5. Nitrate removal by Acorus calamus and total $\mathrm{N}$ in tissues.

\begin{tabular}{|c|c|c|c|c|c|}
\hline $\mathrm{N}$ level & Week & $\begin{array}{c}\mathrm{N} \text { mean } \\
\text { removal }(\mathrm{mg} / \mathrm{L})\end{array}$ & $\begin{array}{l}\mathrm{N} \text { removed at the end } \\
\text { of } 5 \text { th week }(\mathrm{mg} / \mathrm{L})\end{array}$ & $\begin{array}{l}\% \text { removal at the end } \\
\text { of } 5 \text { th week }\end{array}$ & $\begin{array}{l}\text { Total nitrogen } \\
\text { (mg/g) in tissues }\end{array}$ \\
\hline 5 (mg/L) & 1 & 8.13e & $1.61 \mathrm{a}$ & 68 & $16.90 \mathrm{a}$ \\
\hline 15 (mg/L) & 2 & $1.29 \mathrm{c}$ & $2.41 \mathrm{~b}$ & 84 & $17.90 \mathrm{a}$ \\
\hline \multirow[t]{3}{*}{25 (mg/L) } & 3 & $0.27 a$ & $3.32 \mathrm{c}$ & 87 & $20.63 b$ \\
\hline & 4 & $0.71 b$ & & & \\
\hline & 5 & $2.15 \mathrm{~d}$ & & & \\
\hline
\end{tabular}

abilities of Acorus calamus, Scirpus validus, Phragmites australis were 4.85-fold, 6.75-fold, 7.93-fold higher under nitrate concentrations of $25 \mathrm{mg} / \mathrm{L}$ than under nitrate concentrations of $5 \mathrm{mg} / \mathrm{L}$, respectively.

\subsection{Variation in $\mathrm{pH}$ and DO in Nitrate-Contaminated Water}

At the beginning of the experiment, the $\mathrm{pH}$ of the water was 6.8, which changed over time; the $\mathrm{pH}$ in the treatment of different nitrate exhibited a trend of first increasing and then decreasing, finally returning to close to the 
initial pH (Table 6). Early in the experiment, the water pH increased dramatically. In the second week, the pH appeared to be at a maximum; in the Acorus calamus system, the $\mathrm{pH}$ was lower than that in the reed and bulrush systems: the $\mathrm{pH}$ of the reed and bulrush system was between 9.22 and 9.77, whereas that of the Acorus calamus system was between 8.56 and 8.71 , both of which were significantly different from the $\mathrm{pH}$ in the control treatment. After two weeks, all of the treatments decreased in $\mathrm{pH}$. The $\mathrm{pH}$ decreased to the lowest value in the fourth week, but a slight increase occurred in the 5th week. Overall, at the end of the experiment, the $\mathrm{pH}$ was higher than the initial level, and the $\mathrm{pH}$ was significantly higher than in the control group.

Table 6 shows that DO peaked in the water at two weeks and four weeks. At the beginning of the experiment, the DO in each treatment increased, reaching a maximum value at two weeks, and the DO content in each treatment was higher than in the control. The DO content was highest in the reed system, at $12.18 \mathrm{mg} / \mathrm{L} \mathrm{DO}$, which gradually decreased with time. Among the treatments without significant changes, at two weeks before the test, the DO content in the water was significantly lower than in the control, but three weeks later, the DO content began to decrease. At the end of the experiment, the content of DO in all three plant systems was lower than in the control, indicating that none of the three aquatic species resulted in a notable increase in oxygen containing nitrate in water.

\section{Discussion}

This study found that three species of emergent plants have a significant effect on nitrate removal, and the nitrate removal percentage varies with the plant species and the initial concentration. The removal of nitrate primarily depends on its absorption by plants (5\%-23\%) and microbial assimilation [16]-[18]. Plant roots form the aerophilic zone, and the anaerobiotic zone is away from the roots. The anaerobiotic zone varies depending on the available carbon source and can exhibit aerophilic, anoxic and anaerobic conditions [19]. The roots of aquatic plants form a variety of micro-environments around them, which can be conducive to the growth of nitrifying bacteria or denitrifying bacteria [20]. A previous study showed that the removal of nitrate by aquatic plants involved both absorption by plants and the effect of microorganisms [21]. Denitrification plays a major role [6]. In previous experiments, in the presence of only nitrate, plants released $\mathrm{OH}^{-}$or $\mathrm{HCO}_{3}^{-}$via the rhizosphere and maintained a balance of ions [22], higher $\mathrm{pH}$ and DO inhibited denitrification [6], and the water $\mathrm{pH}$ and DO increased over time; therefore, early steep nitrate declines were mainly the result of plant uptake. After two weeks, the water $\mathrm{pH}$ and $\mathrm{DO}$ began to gradually decline, which may resulted from denitrification by microorganisms in

Table 6. Final pH and DO under different treatments.

\begin{tabular}{|c|c|c|c|c|c|c|c|c|c|c|}
\hline \multirow{2}{*}{ Treatment } & \multicolumn{2}{|c|}{$1 \mathrm{~W}$} & \multicolumn{2}{|c|}{$2 \mathrm{~W}$} & \multicolumn{2}{|c|}{$3 \mathrm{~W}$} & \multicolumn{2}{|c|}{$4 \mathrm{~W}$} & \multicolumn{2}{|c|}{$5 \mathrm{~W}$} \\
\hline & $\mathrm{pH}$ & DO & $\mathrm{pH}$ & DO & $\mathrm{pH}$ & DO & $\mathrm{pH}$ & DO & $\mathrm{pH}$ & DO \\
\hline S5 & $7.40 \mathrm{c}$ & $6.53 b$ & $9.22 \mathrm{c}$ & $9.70 \mathrm{~b}$ & $7.58 \mathrm{~b}$ & $4.05 c$ & $7.21 b$ & $4.37 \mathrm{a}$ & 7.34b & $4.07 \mathrm{c}$ \\
\hline P5 & $7.45 \mathrm{~d}$ & $6.54 \mathrm{~b}$ & $9.40 \mathrm{~d}$ & $11.78 \mathrm{c}$ & $7.66 \mathrm{~b}$ & $3.86 \mathrm{~b}$ & 7.30a & 5.12ab & 7.79c & $4.39 \mathrm{~b}$ \\
\hline A5 & 7.33b & 6.19a & $8.56 b$ & 9.90c & $7.14 \mathrm{a}$ & $3.45 a$ & $7.25 b$ & $5.70 \mathrm{bc}$ & $7.38 \mathrm{~b}$ & $3.62 \mathrm{a}$ \\
\hline CK5 & $7.21 \mathrm{a}$ & $6.18 \mathrm{a}$ & 8.13a & 8.53a & $7.15 a$ & $6.05 d$ & 7.09a & $6.23 \mathrm{~d}$ & 7.16a & $5.23 \mathrm{~d}$ \\
\hline S15 & 7.37b & $6.17 \mathrm{~b}$ & $9.29 c$ & $10.34 \mathrm{~b}$ & $7.73 c$ & $4.02 \mathrm{~b}$ & 7.30b & $4.42 \mathrm{a}$ & $7.44 \mathrm{c}$ & $3.67 \mathrm{a}$ \\
\hline P15 & $7.49 \mathrm{c}$ & $6.42 \mathrm{~b}$ & $9.77 d$ & $12.88 \mathrm{~d}$ & $7.98 \mathrm{~d}$ & $4.21 \mathrm{c}$ & $7.35 \mathrm{c}$ & $6.21 b$ & $7.48 \mathrm{c}$ & $4.12 \mathrm{~b}$ \\
\hline A15 & $7.28 \mathrm{a}$ & $6.49 c$ & $8.71 b$ & $11.26 \mathrm{c}$ & $7.34 \mathrm{~b}$ & $3.94 \mathrm{a}$ & $7.33 c$ & 4.86a & $7.39 b$ & $4.15 \mathrm{~b}$ \\
\hline CK15 & 7.25a & $6.23 a$ & $8.24 a$ & $8.64 a$ & $7.09 a$ & 5.39d & 7.14a & $6.65 b$ & 7.24a & $5.49 \mathrm{c}$ \\
\hline S25 & $7.41 \mathrm{bc}$ & $7.42 \mathrm{~d}$ & $9.66 c$ & $11.68 \mathrm{c}$ & $7.59 b$ & $4.34 \mathrm{c}$ & $7.37 \mathrm{c}$ & $3.26 \mathrm{a}$ & $7.68 c$ & $3.67 \mathrm{a}$ \\
\hline P25 & $7.46 \mathrm{c}$ & $6.83 c$ & $9.63 c$ & $11.87 \mathrm{~d}$ & $7.81 \mathrm{c}$ & $3.38 \mathrm{a}$ & $7.37 \mathrm{c}$ & $6.38 c$ & 7.62c & $4.14 \mathrm{c}$ \\
\hline A25 & $7.34 b$ & $6.52 b$ & $8.66 b$ & $9.68 b$ & $7.25 a$ & $3.92 b$ & $7.20 \mathrm{~b}$ & $4.24 \mathrm{~b}$ & $7.35 \mathrm{~b}$ & $3.98 \mathrm{~b}$ \\
\hline CK25 & 7.19a & $6.32 \mathrm{a}$ & 8.30a & 9.01a & $7.23 a$ & $5.38 \mathrm{~d}$ & $7.06 a$ & 6.93d & 7.13a & 5.53d \\
\hline
\end{tabular}

Note: a, b, and c show the differences in $\mathrm{pH}$ and $\mathrm{DO}$ under the same nitrate concentration in different plants $(P<0.05)$. 
the water that enhanced the release of alkaline substances [15]; in addition, plant exudates for mineralization, root turnover, and the assimilatory nitrate reduction process will produce some ammonium [23] [24], leading to declines in plant nitrate absorption and an increase in denitrification.

In this study, three emergent macrophytes provided substantial purification effects in terms of nitrate removal (with nitrate removal percentages exceeding 50\%): Acorus calamus had a nitrate median removal percentage of 79\%, whereas Scirpus validus and Phragmites australis exhibited average removal percentages of $69 \%$ and 63\%, respectively. Acorus calamus exhibited rapid growth, which was conducive to nitrate uptake. In addition, the thick roots and extensive root zone of Acorus calamus release oxygen, provide attachment sites and indirectly promote root microbe activity [16], which improves the purification efficiency in water. Xu [6] and Ran [25] showed that reeds and Acorus calamus exhibited slightly different nitrate removal percentages under different concentrations of nitrate in the water; the present study found that three aquatic species had increased nitrate removal percentages with increased concentrations of nitrate in water and consistent increases in the plant fresh weight This study also found that the three species of plants under the same concentrations of nitrate exhibited significant differences in purification ability $(P<0.05)$ and that Acorus calamus' purification ability was significantly lower than those of Scirpus validus and Phragmites australis. This difference exists because emergent plants have high nitrate purification abilities and the capacity for nitrate removal was determined according to the fresh weight (Equation (2)). In all three species and under all three concentrations, the nitrate content exhibited a sharp decline in the early stages and later decreased more slowly; this pattern may have occurred because at the beginning of the experiment, the plants used a large amount of nitrate, and in the latter stages, the plants' nutrient requirements were reduced. Element redistribution may also have been a factor, causing the plants' nitrate absorption from water and utilization rate to gradually slow down [5]. After 4 weeks of treatment, a small peak in nitrate content began to decrease in the Acorus calamus treatment, and the Scirpus validus and Phragmites australis treatments also exhibited a significant decrease in nitrate (Table 3). In this case of Acorus calamus, the nitrate removal percentages may have been affected by nitrate serving as a direct substrate for bacteria in the roots, which are the most active plant organ [7], and the Acorus calamus system $\mathrm{pH}$ and DO were significantly lower than those in the Scirpus validus and Phragmites australis systems as a result of the increased microbial denitrification capacity, which may also be related to the growth characteristics of the plants. Therefore, under the same number of plants, Acorus calamus' nitrate nitrogen removal efficiency per unit fresh weight was significantly the lowest, mainly because Acorus calamus has a large and active root system.

\section{Conclusion}

The results in this paper demonstrated that the concentration of nitrate, species of aquatic plant and their interaction significantly impacted the effect of nitrate removal. Acorus calamus provided the most effective purification of nitrate wastewater under the same number of plants in all three concentrations of nitrate wastewater, but in terms of the purification ability by unit fresh weight, Scirpus validus and Phragmites australis had a stronger purification capacity than Acorus calamus.

\section{Acknowledgements}

This project was supported financially by the National scientific research projects of China (20120401-7) and Major water conservancy projects in Shandong Province (NO.SDSLKY201231). Thanks to our ecological team.

\section{References}

[1] Zhang, Z., Lin, Y. and Liang, J. (2002) Water Eutrophication and Controls, Vol. 24. Environmental Science, Chongqing, 52-54.

[2] L'hirondel, J.L., Avery, A.A. and Addiscott, T. (2006) Dietary Nitrate: Where Is the Risk? Environmental Health Perspectives, 11, A458. http://dx.doi.org/10.1289/ehp.114-a458c

[3] Mizuta, K., Matsumoto, T., Hatate, Y., Nishihara, K., Nakanishi, T. and Tomoki, N. (2004) Removal of Nitrate-Nitrogen from Drinking Water Using Bamboo Powder Charcoal. Bioresource Technology, 95, 255-257. http://dx.doi.org/10.1016/j.biortech.2004.02.015

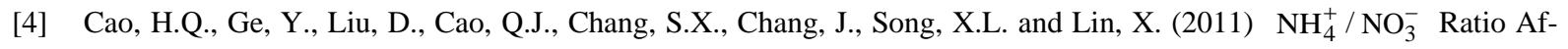
fect Ryegrass (Lolium perenne L.) Growth and N Accumulation in a Hydroponic System. Journal of Plant Nutrition, 


\section{4, 206-216. http://dx.doi.org/10.1080/01904167.2011.533322}

[5] Li, X., Masuda, H., Koba, K. and Zeng, H. (2007) Nitrogen Isotope Study on Nitrate-Contaminated Groundwater in the Sichuan Basin, China. Water, Air, \& Soil Pollution, 178, 145-156. http://dx.doi.org/10.1007/s11270-006-9186-y

[6] Xu, X.Z., Huang, C.C., Xu, Q.S., Jiang, Q.S., Gu, B.J., Chang, J. and Ge, Y. (2012) Effect of Plant Diversity on Nitrate Removal In Simulated Constructed Wetlands. Chinese Journal of Ecology, 31, 1150-1156.

[7] Tong, C.H., Yang, X.E. and Pu, P.M. (2004) Purification of Eutrophicated Water by Aquatic Plant. Chinese Journal of Applied Ecology, 15, 1448-1450.

[8] World Health Organization (WHO) (1993) Guidelines for Drinking-Water Quality: Recommendations. World Health Organization, Geneva.

[9] Jiang, X.Y., Zhai, J.P., Huang, L. and Nie, R. (2006) Experimental Study on Enrichment of Nitrogen and Phosphor in Several Hydrophytes. Environmental Protection Science, 32, 13-16.

[10] Liu, P., Song, C., Zhu, H., Zhang, Q.J. and Jia, C.X. (2011) Studies on Eutrophicated Water Quality Improvement by Three Kinds of Hydrophytes. Journal of Hydroecology, 32, 69-73.

[11] Liu, X.D., Li, J., Gong, Y.F., Zhou, Y.F., Zhu, Z.G. and Zhou, Z.Q. (2013) Purification of Eutrophic Water by Five Aqua-Cultured Plants. Chinese Journal Environmental Engineering, 7, 2607-2612.

[12] Tang, X.Q., Li, J.Z., Li, X.J., Liu, X.G. and Huang, S.L. (2007) Research on Seven Hydrophytes' Removal Effect on Nitrogen and Phosphorus in Eutrophic Water. Journal of Subtropical Resources and Environment, 2, 8-14.

[13] Achintya, N., Bezbaruah, T. and Zhang, C. (2004) pH, Redox and Oxygen Microprofiles in Rhizosphere of Bulrush (Scirpus validus) in a Constructed Wetland Treating Municipal Wastewater. Biotechnology and Bioengineering, 88, 61-70.

[14] Armstrong, W., Cousins, D., Armstrong, J., Turner, D.W. and Beckett, P.M. (2000) Oxygen Distribution in Wetland Plant Roots and Permeability Barriers to Gas-Exchange with the rhIzosphere: A Microelectrode and Modelling Study with Phragmites australis. Annals of Botany, 86, 687-703. http://dx.doi.org/10.1006/anbo.2000.1236

[15] Rao, T.P., Yano, K., Iijima, M., Yamauchi, A. and Tatsumi, J. (2002) Regulation of Rhizosphere Acidification by Photosynthetic Activity in Cowpea (Vigna unguiculata l. Walp.) Seedlings. Annals of Botany, 89, 213-220. http://dx.doi.org/10.1093/aob/mcf030

[16] Wang, G.X., Pu, P.M., Huang, Y.K. and Zhang, S.Z. (1998) Distribution and Role of Denitrifying, Nitrifying, Nitrosation and Ammonifying Bacteria in the Taihu Lake. Chinese Journal of Applied \& Environmental Biology, 5, 190-194.

[17] Ge, Y., Li, S.P., Niu, X.Y., Yue, C.L., Xu, Q.S. and Chang, J. (2007) Sustainable Growth and Nutrient Uptake of Plants in a Subtropical Constructed Wetland in Southeast China. Fresenius Environmental Bulletin, 16, 1023-1029.

[18] Yang, M., Wu, X.G., Zhou, L.F. and Zhang, W.H. (2007) Study on the Capacity of Purification of Acorus calamus L. in Eutrophic Water of Different Degree. Environmental Science and Management, 32, 77-79.

[19] He, R., Zhou, Q. and Zhang, J. (2004) Treating Domestic Sewage by the Free-Water Surface Constructed Wetlands. Ecology and Environment, 13, 180-181.

[20] Wu, Z.B., Qiu, D.R., He, F., Fu, G.P., Cheng, S.P. and Ma, J.M. (2003) Effects of Rehabilitation of Submerged Macrophytes on Nutrient Level of a Eutrophic Lake. Chinese Journal of Applied Ecology, 14, 1352-1353.

[21] Chong, Y.X., Hu, H.Y. and Qian, Y. (2003) Advances in Utilization of Macrophytes in Water Pollution Control. Techniques and Equipment for Environmental Pollution Control, 4, 36-40.

[22] Hinsinger, P., Plassard, C., Tang, C. and Jaillard, B. (2003) Origins of Root-Mediated pH Changes in the Rhizosphere and Their Responses to Environmental Constraints: A Review. Plant Soil, 248, 43-59. http://dx.doi.org/10.1023/A:1022371130939

[23] Ngugi, D.K., Ji, R. and Brune, A. (2011) Nitrogen Mineralization, Denitrification, and Nitrate Ammonification by Soil-Feeding Termites: A 15N-Based Approach. Biogeochemistry, 103, 355-369. http://dx.doi.org/10.1007/s10533-010-9478-6

[24] Rütting, T., Boeckx, P., Müller, C. and Klemedtsson, L. (2011) Assessment of the Importance of Dissimilatory Nitrate Reduction to Ammonium for the Terrestrial Nitrogen Cycle. Biogeosciences, 8, 1779-1791. http://dx.doi.org/10.5194/bg-8-1779-2011

[25] Ran, N., Agami, M. and Oron, G. (2004) A Pilot Study of Constructed Wetlands Using Duckweed (Lemna gibba L.) for Treatment of Domestic Primary Effluent in Israel. Water Research, 38, 2240-2247. http://dx.doi.org/10.1016/j.watres.2004.01.043 